\title{
Da generalidade do conceito do direito
}

E' lei sociologica, induzida da observação, directa e indirecta, dos factos, que o individuo só vive e desenvolve-se na sociedade.

Viver em sociedade é para elle uma necessidade imposta pela sua natureza.

E' outra lei sociologica, igualmente induzida da observação, directa e indirecta, dos factos, que a sociedade só é possivel, restringindo cada consociado a sua actividade. Esta restricção é uma necessidade imposta pela natureza da sociedade, e tão imperiosa é, que os proprios animaes, instinctivamente, com ella se conformam.

As sociedades de abelhas, de castores e de formigas não subsistiriam, si cada um dos seus respectivos membros não se mantivesse dentro de certa esphera de actividade e não respeitasse a actividade dos outros consociados. Sem essa restricção mutua de actividade por parte das unidades sociaes, impossivel seria o equilibrio das espheras de actividade individual na coexistencia social. E', pois, condição sine qua nou da sociedade.

Nestas duas leis fundamentaes da sociologia assenta o conceito do direito. Todo o conjuncto das normas juridicas, quaesquer que ellas sejam, de ordem publica ou privada, de ordem nacional ou internacional, é um sys.tema de limitações impostas, pela necessidade incoercivel da vida em communhão, á esphera de actividade de cada unidade social, sendo por conseguinte tambem, sob outra face, um systema de faculdades, que determina o que a cada um é licito fazer ou deixar de fazer. 
Todas as instituições juridicas são deduções do principio da restricção da actividade das unidades sociaes. Ha uma série de restrições a essa actividade no direito das coisas, no direito das obrigações, no direito da familia, no direito da successão, no direito publico interno, no direito publico externo, tambem chamado direito internacional, em que as unidades sociaes são os estados, membros da communhão internacional.

Essa limitação da actividade é uma condição primordial de vida para a sociedade e para o individuo, que fóra della não póde viver e desenvolver-se. Para que a sociedade se conserve e desenvolva, e o mesmo aconteça ao individuo ou á entidade collectiva formada no seio da mesma sociedade, é imprescindivel que cada. uma destas unidades sociaes tenha uma esphera de acção, dentro da qual realize tudo que lhe é condição de vida e desenvolvimento, sem impedir os consociados, ou as outras collectividades, de se conservarem e desenvolverem. Ahi está o principio fundamental do direito. Ahi está a base em que assenta o conceito correcto do direito no estadio actual de sua evolução, conceito que, como se vê, extende-se a todos os ramos da sciencia juridica, sem distincção (Conf. meus Ensaios de philosophia do direito, $\S 110$, e o dr. Pedro Lessa, Estudos de philosophia do direito, pags. 379 e seguintes). Si quizermos saber si um acto qualquer deve ou não ser permittido pelo direito, cumpre indagar si a pratica desse acto é, para o homem na sociedade dos individuos, ou para o estado na sociedade internacional dos estados, uma condição de vida e desenvolvimento, cuja realização não impeça que seus similhantes igualmente se conservem e desenvolvam. A harmonia da coexistencia social dos individuos no estado, e dos estados na communhão internacional, funda-se no exposto conceito do direito, que abrange todos os departamentos juridicos. 
E' verdade que o direito internacional, que constitúe o mais novo. destes departamentos, parece, ao ver de alguns auctores, repellir este conceito. Entretanto, é uma apparencia enganosa, e o engano deve desapparecer deante desta distincção: o direito internacional está actualmente na phase em que esteve, ha muitos seculos, o direito nacional. Este, em estado muito mais adeantado, tem hoje para realizal-o, o estado politicamente organizado, com um poder legislativo, um poder executivo e um poder judiciario.

Aquelle não dispõe ainda, sinão de ensaios destes elementos, que virão mais tarde com 'a organização politica regular da federação mundial, contendo em sua estructura aquelles tres poderes.

Esta mera circumstancia de tempo não é, porém, razão scientifica para que o conceito do direito internacional seja diverso do conceito do direito nacional e esteja na boca dos canhões das potencias mais fortes.

São Paulo, 10 de fevereiro de 1912.

Dr. José Mendes. 